\title{
Research on the Development of Undergraduates' Entrepreneurship Technology Enterprises under the Policy of National University Science Parks
}

\author{
Hanwen Li, Mingyu Li and Kun Zhang* \\ College of Ocean Information Engineering, Hainan Tropical Ocean University, Sanya, Hainan, \\ 572022, China \\ kunzhang@hainu.edu.cn
}

\begin{abstract}
Keywords: National university science and technology park; Small micro enterprises; College students entrepreneurship
\end{abstract}

\begin{abstract}
The paper analyzes the development factors and existing problems of small micro-tech enterprises. Taking the growth experience of Sanya Yunxin Technology Development Co., Ltd. in Qiongzhou University National University Science Park as an example, this paper analyzes and studies the direction of development of the similar micro-science on National University Science Park Platform, playing a role of demonstration and significance.
\end{abstract}

\section{Introduction}

The 18th National Congress of the Communist Party of China put forward the implementation of innovation-driven development strategy, which clearly calls for improved scientific research and achievement transformation. As an important driver of innovation-driven development and the core carrier of science and technology service industry, science and technology park needs comprehensive scientific and technological resources, and continuously improve the quality of science and technology services. In 2014, the State Council "to speed up the development of science and technology services, a number of opinions" proposed by 2020, to basically form a full range of scientific and technological innovation covering science and technology service system. In 2015, the General Office of the CPC Central Committee and the General Office of the State Council, "Deepening the implementation of the reform of science and technology system," put forward, to improve the market-oriented mechanism of technological innovation and government guidance mechanism to strengthen the collaboration of industry-university research and innovation to maximize the enterprise and market vitality, Under this background, concerned about the market, the government, colleges and universities how to set up a new science and technology service organization through capital, to achieve the policy of intellectual, capital and other core technology services coupling, is a feasible direction of exploration.

\section{Science and technology park science and technology service mode evolution}

In the 1980s, professional financial services organizations such as angel funds and venture capitalists emerged in science and technology parks. Each technological change will lead to the rise of new industries. Science and technology service organizations to further promote the industry to further streamlining the division of labor, professional services due to industry and Japan. New technologies and new industries are emerging in the 21st century, and the product life cycle is becoming shorter. Enterprise diversification, personalized service needs to upgrade, scientific and technological services division of labor, science and technology service chain continues to extend. In order to achieve maximum efficiency, the service organization that participates in the division of service chain will specialize and modularize one or several service chain links and make it networked on the basis of link. 
Science and technology service organizations through efficient competition and cooperation, the combination of resources and the formation of a highly flexible professional services and cooperation alliance. For example, business incubators are mainly government agencies, non-profit economic development organizations and academic institutions, is the government-driven non-profit organizations. Enterprise accelerator is based on the profitability of business entities and venture capital, by academic institutions, government organizations, economic development organizations and other diversified services consisting of the main enterprise network. The government plays a different role between the two governments, the government plays a leading role in accelerating the development of the accelerator, the market plays a leading role; the government plays a key role in the development of the incubator, and the market plays a facilitating role.

In general, science and technology small and micro enterprises refers to the knowledge, technology, talent-intensive economic entities. Such enterprises pursue innovation, and are committed to the scientific and technological achievements into practical productive forces, mainly engaged in technology and product development and production, sales and service. Because at present college students hardly have the ability and experience of high-end technology and product development, this article will include science and technology-derived products and services in science and technology In the definition of small and micro enterprises, as a university science and technology park enterprises, good development should be strengthened from the following points.

\section{Promote the construction of campus entrepreneurial culture, cultivate students' entrepreneurial spirit}

The connotation of entrepreneurship ability model and the characteristics of science and technology small and micro enterprises determine that colleges and universities must pay attention to the culture of campus entrepreneurship. First of all, most of the students who participate in the start-up of small and medium-sized science and technology enterprises are science and engineering students. The cultural cultivation of entrepreneurial culture can broaden their social horizon and develop their ability of judgment and thinking. Scientific research pays attention to logical thinking, and it does not seem to be related to the image thinking that humane education places emphasis on. However, the two are intertwined, promoted and developed together. Only by building a good campus entrepreneurial culture and carrying out humanities education can we promote the comprehensive and balanced development of the entrepreneurship ability of science and engineering students. Second, the target capacity and commitment capacity in the entrepreneurial capacity model occupy a relatively large proportion, which shows that colleges and universities should pay more attention to the cultivation of deep-rooted abilities such as target ability and commitment capability. On the one hand, they should target themselves to individualize teaching, promote entrepreneurship education reform, Abandon the old-fashioned part of the traditional education; on the other hand, we should also strengthen the building of a campus culture with the theme of "entrepreneurship", vigorously publicize the significance of starting a business, promote the entrepreneurial spirit, create a culture of entrepreneurial culture, and arouse students' enthusiasm for starting a business.

\section{Establish practical training base and actively promote school-enterprise cooperation}

From the entrepreneurial capacity model constructed above, we can see that relational ability, learning ability, organizational ability, innovation ability and opportunity ability all have strong practical orientation. All of these abilities need to be cultivated in "learning by doing". For example, innovation and innovation is a practice in itself. Some innovations aimed at products and services are born out of direct contact and interaction with the market and customers. For another example, most interviewees think that it is very important to evaluate the feasibility of business opportunities through practical experiments, and the 
repeated practice of recognizing the chances of success can be learned. Therefore, colleges and universities should pay great attention to students' entrepreneurship training, the importance of which in a sense even more than the education of their entrepreneurial theory. Specific measures include: first of all to establish well-equipped, technologically advanced training base within the school, training students through practical training theory combined with the actual ability; at the same time, actively seek cooperation between schools and enterprises, build a platform, with all kinds of business information and advantages Technical Advantages Guidance and help students to enable students to perceive the corporate culture in advance, understand the staffing and institutional management information necessary for the operation of enterprises, lay a practical foundation for entrepreneurship.

\section{Constructing Entrepreneurial Ability Cultivation System Based on Triple Helix Theory}

The theory of triple helix put forward by Henry Eckowitz et al. Is used to analyze the theory of complex and interactive relations among universities, government and industry in economic development in the era of knowledge economy. Which led the university knowledge innovation, industry-led technological innovation, and government-led policy innovation. All three of them not only maintain their own independence, but also penetrate each other to achieve the overall effectiveness of the spiral. From the perspective of triple-helix theory, it is necessary to give full play to the independent role of universities, industries and government in building entrepreneurial cultivation mechanism for university students in science and technology small and micro enterprises, and also to promote the interaction between the three to maximize the overall effectiveness. In other words, first, universities not only need to promote the culture of campus entrepreneurship and school-enterprise cooperation, but also need to call for and seek more financial support from the government to formulate effective entrepreneurial support policies to improve the entrepreneurial environment; second, the industry not only We need to actively promote the cooperation between universities and enterprises and give play to the role of technology transformation. We also need to supervise the service functions of the government, make recommendations for the government's entrepreneurial environment and promote the development of government functions. Thirdly, the government not only needs to create a good entrepreneurial environment, It is also necessary to work closely with schools and implement concrete measures to remove the invisible wall that hinder students and enterprises and social ties.

\section{Summary}

Small micro-network companies should be based on their own characteristics, combined with their own industries and the current external environment, develop development strategies, seize the current opportunities, improve competitiveness, break through the development of "bottleneck" to achieve "Internet $+"$ transformation and upgrading.

It is undeniable that the entrepreneurial capability model itself is not yet mature in the application of entrepreneurial management in our country. There are many areas to be improved, but it is still at the initial stage for the entrepreneurship of university students with small and medium-sized technology. In the absence of a large number of effective quantitative analysis and empirical research in the cultivation and evaluation of entrepreneurship ability, there are still many theoretical studies and practical work in this study that need further discussion and exploration. 


\section{Acknowledgement}

This research was financially supported by the 2015 Innovation and Entrepreneurship Training College National College Projects (No.201511100008).

\section{References}

[1] X.B. Tang: Research on Success Critical Factors in the Growth Stage of Technology-based Small and Micro Enterprises (MS., Central South University, China 2014), p.18-38.

[2] S.S. Li: A Study on the Influencing Factors of the Growth of Science and Technology Small and Medium Enterprises in China (MS., Shandong University, China 2014), p.23.

[3] S.S. Li, Y. M. Zhang: Analysis on the Growth Stage of Small and Medium - sized Technological Enterprises and the Countermeasures. Theory Journal, (2013) No.9, p.50-53.

[4] M. Li: Current Situation and Countermeasures of Enterprise Informationization in Wuhan University. Modern Economic Information, (2013) No.3, p.301-302.

[5] T. Zhu: Small micro-network company development path. Management and Administration, (2017) No.7, p.64-66.

[6] Y.F. Wang, M.Y. Li, K Zhang: The Development of Small-micro Technology Enterprises in the Platform of National University Science Park - Take Sanya Yunxin Technology Development Co., Ltd for Example. Advances in Computer Science Research, (2017) Vol. 73, p. 1121-1126. 